\title{
Does the Summer Arctic Frontal Zone Influence Arctic Ocean Cyclone Activity? 0
}

\author{
Alex D. Crawford and Mark C. Serreze \\ Cooperative Institute for Research in Environmental Sciences, National Snow and Ice Data Center, \\ and Department of Geography, University of Colorado Boulder, Boulder, Colorado
}

(Manuscript received 23 October 2015, in final form 10 February 2016)

\begin{abstract}
Extratropical cyclone activity over the central Arctic Ocean reaches its peak in summer. Previous research has argued for the existence of two external source regions for cyclones contributing to this summer maximum: the Eurasian continent interior and a narrow band of strong horizontal temperature gradients along the Arctic coastline known as the Arctic frontal zone (AFZ). This study incorporates data from an atmospheric reanalysis and an advanced cyclone detection and tracking algorithm to critically evaluate the relationship between the summer AFZ and cyclone activity in the central Arctic Ocean. Analysis of both individual cyclone tracks and seasonal fields of cyclone characteristics shows that the Arctic coast (and therefore the AFZ) is not a region of cyclogenesis. Rather, the AFZ acts as an intensification area for systems forming over Eurasia. As these systems migrate toward the Arctic Ocean, they experience greater deepening in situations when the AFZ is strong at midtropospheric levels. On a broader scale, intensity of the summer AFZ at midtropospheric levels has a positive correlation with cyclone intensity in the Arctic Ocean during summer, even when controlling for variability in the northern annular mode. Taken as a whole, these findings suggest that the summer AFZ can intensify cyclones that cross the coast into the Arctic Ocean, but focused modeling studies are needed to disentangle the relative importance of the AFZ, large-scale circulation patterns, and topographic controls.
\end{abstract}

\section{Introduction}

The Arctic climate system is strongly shaped by seasonal and spatial patterns of extratropical cyclone activity (Serreze et al. 2007; Serreze and Barrett 2008; Sorteberg and Walsh 2008). As the Arctic Ocean becomes more accessible to shipping, resource extraction, and other activities, the practical importance of understanding Arctic weather patterns grows (Berner et al. 2005; Dodds 2010). While recent years have seen strong advances in understanding the seasonal cycles (e.g., Serreze 1995; Simmonds et al. 2008), interannual

\footnotetext{
Supplemental information related to this paper is available at the Journals Online website: http://dx.doi.org/10.1175/JCLI-D-150755.s1.

Corresponding author address: Alex D. Crawford, Cooperative Institute for Research in Environmental Sciences, National Snow and Ice Data Center, and Department of Geography, University of Colorado Boulder, Campus Box 449, Boulder, CO 80309-0449.

E-mail: alexander.crawford@colorado.edu
}

variability (e.g., Zhang et al. 2004; Serreze and Barrett 2008; Simmonds et al. 2008), and long-term changes (e.g., Serreze et al. 1993; McCabe et al. 2001; Vavrus 2013) in the characteristics, distribution, and climate impacts of Arctic cyclones, much remains to be learned.

The central Arctic Ocean (CAO; inside gray outline in Fig. 1) and the adjacent Beaufort, Chukchi, East Siberian, and Laptev Seas (BCEL) experience substantially more cyclolysis than cyclogenesis in all seasons (Serreze et al. 1993; Serreze and Barrett 2008). In other words, more cyclones fill and dissipate in the Arctic Ocean than form there. This was remarked on by Reed and Kunkel (1960, p. 496), who, based on only limited data, described the Arctic Ocean as a region where cyclones "collect and stagnate." Several subsequent studies have observed that cyclones have a tendency to track northeastward into the Arctic Ocean and then spiral counterclockwise around the CAO, commonly experiencing lysis near the North Pole (e.g., Whittaker and Horn 1984; Serreze and Barrett 2008).

In winter, a majority of cyclones that enter the Arctic Ocean originate within the Icelandic low region and 


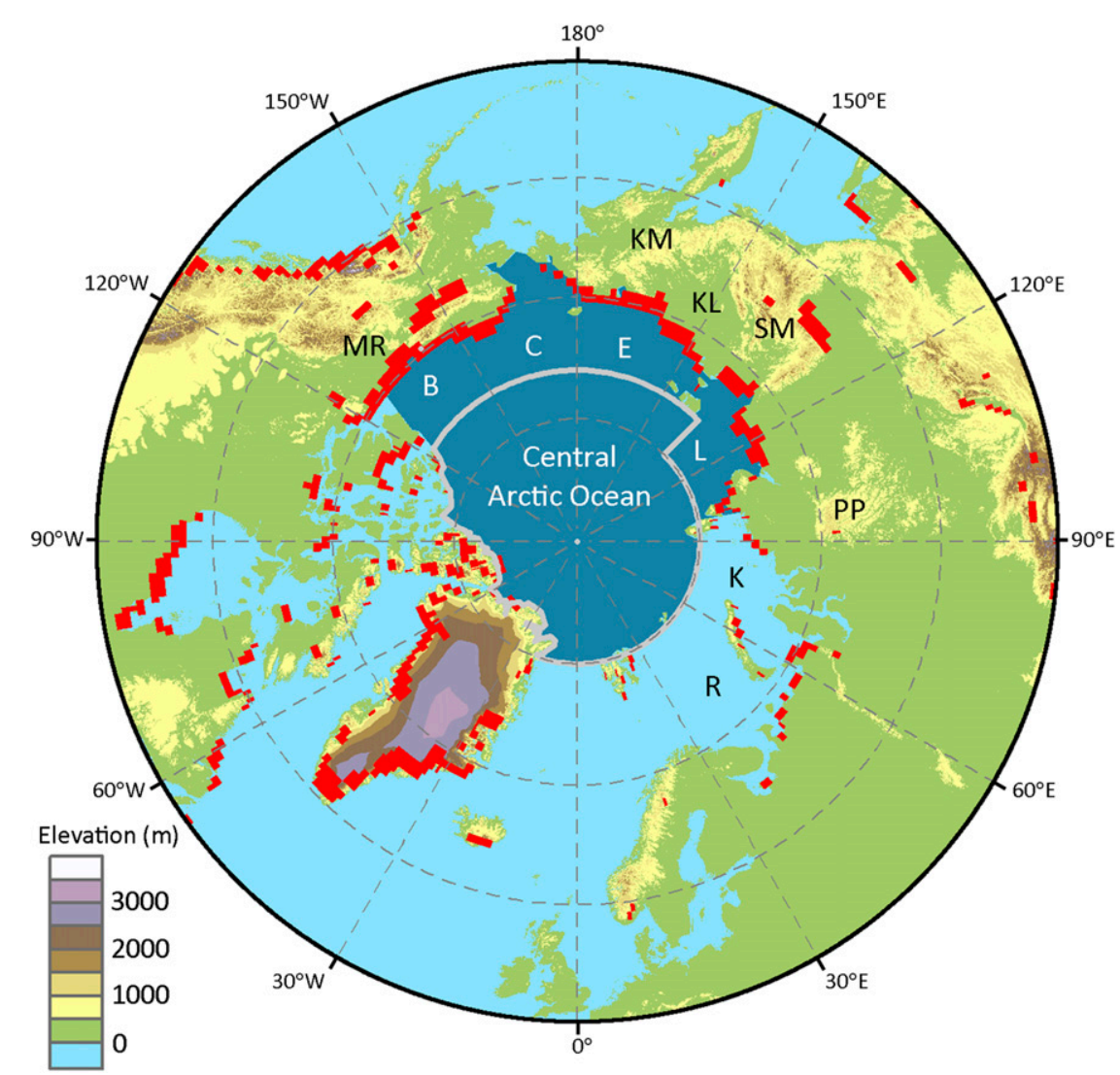

FIG. 1. Location map of Arctic region showing elevation (see color bar). Grid cells for which the MERRA-derived average 2-m meridional temperature gradients for July 1979-2014 exceeded $-3.0 \mathrm{~K}(100 \mathrm{~km})^{-1}$ are colored red. The bold gray line bounds the CAO [following the definition of Welsh et al. (1986)], the surrounding letters denote the coastal Arctic seas [Beaufort (B), Chukchi (C), East Siberian (E), Laptev (L), Kara (K), and Barents (R)], and the dark blue shading indicates the study area (CAO+BCEL). The letter pairs denote specific topographic features that are mentioned in the text [Mackenzie Range (MR); Kolyma Mountains (KM); Kolyma lowland (KL); Verkhoyanski, Cherksi (Cherskogo), and Gydan Mountain ranges (SM); and Putorana Plateau (PP)].

farther south along the North Atlantic storm track (Serreze et al. 1993; Simmonds et al. 2008). These storms tend to migrate northeastward, and accordingly, the highest winter cyclone frequency in the Arctic Ocean is observed in the Barents and Kara Seas (denoted by $\mathrm{R}$ and $\mathrm{K}$ in Fig. 1). Relatively few find their way into the CAO.

Summer stands in sharp contrast. Cyclone frequency in the North Atlantic and Barents Sea is significantly lower (Whittaker and Horn 1984; Serreze et al. 1993; Simmonds et al. 2008), and the cyclones that do form tend to be less intense than their winter counterparts (Serreze et al. 1993; Serreze 1995; Simmonds and Rudeva 2014). However, activity in the CAO in summer is comparable to or even greater than in winter. This was first noted by Dzerdzeevskii (1945) and Reed and Kunkel (1960) and confirmed in subsequent studies using a variety of cyclone detection and tracking algorithms (Zhang et al. 2004; Mesquita et al. 2008; Serreze and Barrett 2008; Simmonds et al. 2008).

Some cyclones contributing to this summer maximum develop locally within the Arctic Ocean (Serreze and Barrett 2008). Baroclinicity along the sea ice margin (Inoue and Hori 2011) and (later in the year) vertical enthalpy fluxes from the open water surface (Ledrew 1984; Simmonds and Keay 2009) may both contribute to local cyclone development. However, it appears that many cyclones found over the Arctic Ocean in summer are generated over $\mathrm{Si}$ beria, especially in the Kolyma lowland (KL in Fig. 1), which lies in the lee of the Verkhoyanski, Cherski (or Cherskogo), and Gydan Mountain ranges (Whittaker and Horn 1984; Serreze 1995; Serreze et al. 2001; Sorteberg and Walsh 2008). Hereafter, these ranges will be referred to collectively as the Siberian mountains (SM in Fig. 1). 
Another regional mechanism that has been linked to summer cyclone development is the summer Arctic frontal zone (AFZ), a band of strong horizontal temperature gradients (Serreze et al. 2011; Crawford and Serreze 2015) and frequent near-surface weather fronts (Reed and Kunkel 1960; Serreze et al. 2001) that stretches along the Arctic coastlines of Eurasia and western North America from $41^{\circ} \mathrm{E}$ eastward to $126^{\circ} \mathrm{W}$. The AFZ develops each spring and summer in response to differential heating of the atmosphere on either side of the coastline. Land, after losing its snow cover, attains higher skin temperatures than the combined sea ice and ocean surface to the north, and these thermal differences are transferred to the atmosphere via differences in the radiative and turbulent heat fluxes on either side of the coastline (Crawford and Serreze 2015). Prior studies have suggested that baroclinic instability associated with the summer AFZ contributes to cyclogenesis near the Arctic coastline (Reed and Kunkel 1960; Serreze et al. 2001; Serreze and Barrett 2008) and therefore influences both cyclone activity and precipitation over the Arctic Ocean (Serreze et al. 2001; Serreze and Barrett 2008). Although based on the common baroclinic instability model of extratropical cyclone development (Eady 1949; Farrell 1985; Pierrehumbert and Swanson 1995), this idea has not yet been rigorously tested.

CAO cyclone frequency exhibits substantial variability from year to year (Serreze and Barrett 2008) and on multiyear scales (Zhang et al. 2004). This has been linked to the phase of the northern annular mode (NAM). Summer cyclone frequency and intensity in the CAO tend to be greater when the NAM is in its positive phase (Zhang et al. 2004; Serreze and Barrett 2008; Simmonds et al. 2008). The AFZ is another potential influence on cyclone's year-to-year variability because it also exhibits substantial year-to-year variation in strength (Ogi et al. 2004; Crawford and Serreze 2015). However, relationships between interannual variability in the summer AFZ and cyclone activity have not yet been considered. This paper advances our understanding of Arctic cyclone activity through a rigorous assessment of the following question: How does variability in the strength of the summer AFZ relate to the development of cyclones affecting the CAO?

\section{Methods}

\section{a. Data sources}

All gridded data used for this study were obtained from the National Aeronautics and Space Administration's (NASA) Modern-Era Retrospective Analysis for Research and Applications (MERRA; Rienecker et al.
2011), which is one of several modern atmospheric reanalyses that generate gridded fields of atmospheric variables using a single atmospheric model and assimilation system to blend model output and observational data (Saha et al. 2010). MERRA is generated using version 5.2.0 of the Goddard Earth Observing System (GEOS) atmospheric model and assimilation system. The assimilation system is a three-dimensional variational data assimilation and uses gridpoint statistical interpolation (Rienecker et al. 2011). The native resolution is $0.67^{\circ}$ longitude by $0.50^{\circ}$ latitude and 72 vertical levels.

All data were obtained for the period 1979-2014 from the MERRA data-subsetting webtool (http://disc.sci.gsfc. nasa.gov/daac-bin/FTPSubset.pl), which is managed by the Global Modeling and Assimilation Office (GMAO) and Goddard Earth Sciences Data and Information Services Center (GES DISC). Temperature, geopotential height $(\mathrm{GPH})$, and the zonal and meridional wind components were obtained at 6-hourly intervals for several vertical levels $(600,500$, and $400 \mathrm{hPa}$ for all variables, as well as 1000-hPa GPH and 2-m and 700-hPa temperature). For cyclone detection (described below) sea level pressure (SLP) was obtained at 3-h time steps and a reduced resolution of $1.125^{\circ}$ longitude by $1.125^{\circ}$ latitude.

Since the NAM has been previously linked to interannual variability in Arctic cyclone activity, the monthly index of the seasonally variable NAM (SVNAM; Ogi et al. 2004) is also examined. Monthly values for 1979-2011 were obtained from JAMSTEC (http://www.jamstec.go.jp/res/ ress/masayo.ogi/SVNAM.txt).

\section{b. Calculation of EGR and AFZ strength}

The maximum Eady growth rate (EGR) is a common value used in synoptic research (e.g., Walter and Graf 2005; Serreze and Barrett 2008; Simmonds and Rudeva 2012) that relates baroclinic instability to the vertical wind shear and static (in)stability (Vallis 2006). In other words, it measures how conducive the environment is to synoptic development. Following Serreze and Barrett (2008) and Simmonds and Rudeva (2012), EGR was calculated as follows:

$$
\mathrm{EGR}=0.3098 \frac{|f| \frac{\partial V(z)}{\partial z}}{N},
$$

where $f$ is the Coriolis parameter, $V(z)$ is the vertical profile of the horizontal wind, $z$ is the vertical coordinate, and $N$ is the Brunt-Väisälä frequency $\left[N^{2}=\right.$ $(g / \theta)(\partial \theta / \partial z)$, where $g$ is acceleration due to gravity, $\theta$ is potential temperature, and $z$ is the vertical coordinate]. For calculation of EGR at $500 \mathrm{hPa}$, the vertical profiles of $V$ and $\theta$ were calculated as the difference between their values at 400 and $600 \mathrm{hPa}$. 
a)

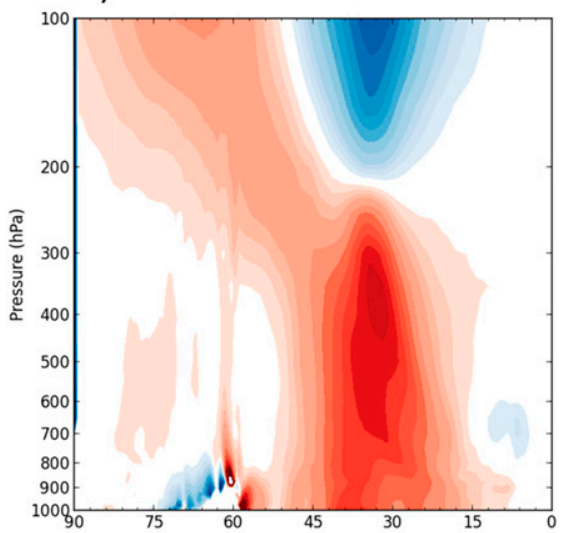

c)
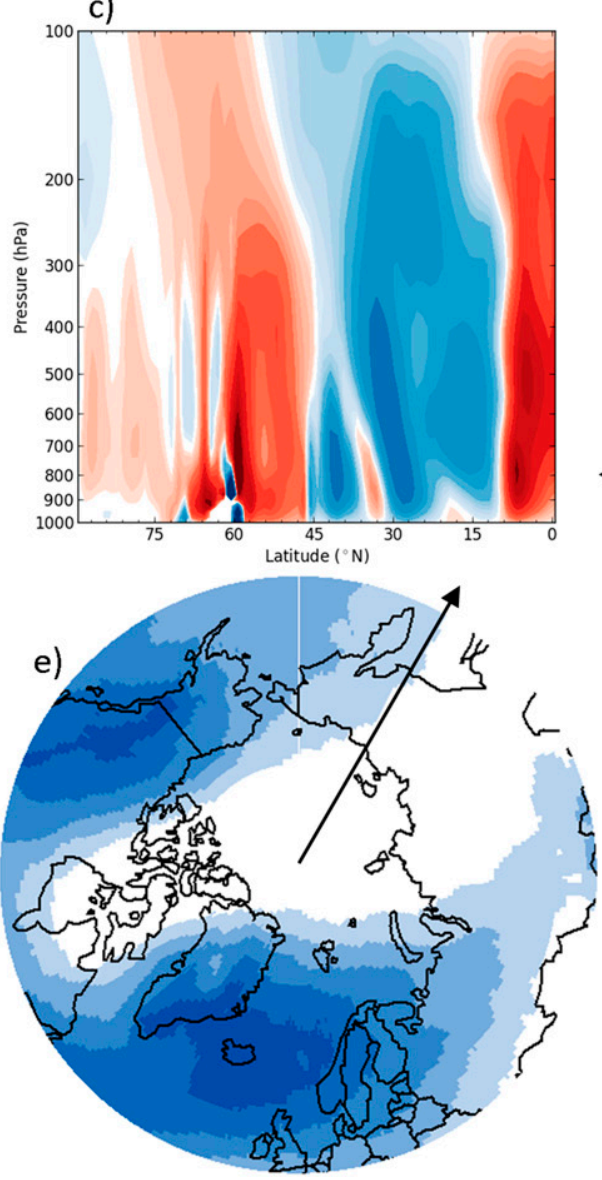

b)

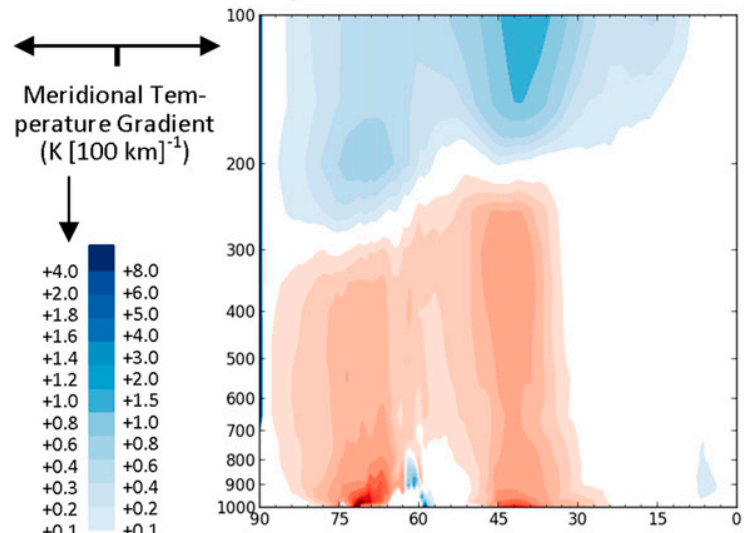

d)
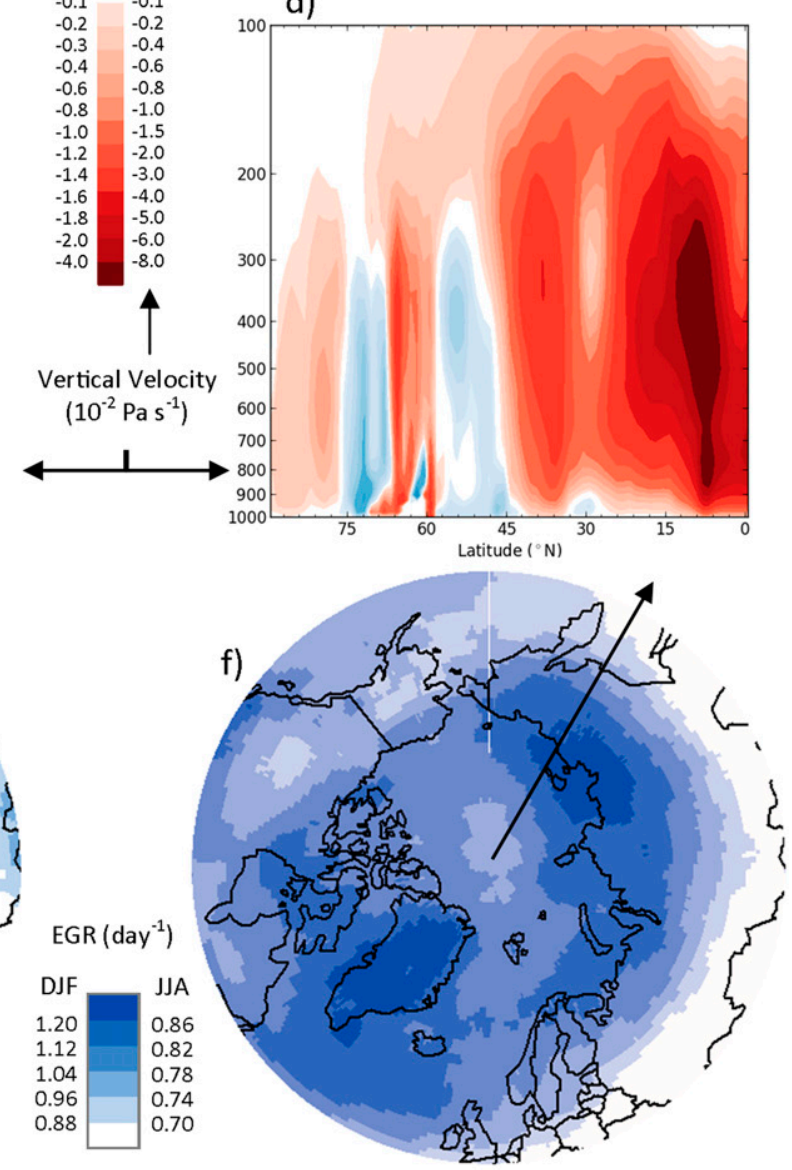

FIG. 2. Latitudinal cross sections along $151^{\circ} \mathrm{E}$ longitude for (a),(b) average meridional temperature gradient $\left[\mathrm{K}(100 \mathrm{~km})^{-1}\right]$ and (c),(d) vertical velocity $\left(10^{-2} \mathrm{~Pa} \mathrm{~s}^{-1}\right)$ for (a),(c) January and (b),(d) July 1979-2014 and (e),(f) maps of average EGR at $500 \mathrm{hPa}\left(\mathrm{day}^{-1}\right.$ ) for (e) winter (DJF) and (f) summer (JJA) 1979-2014.

As in Crawford and Serreze (2015), AFZ strength at any particular location and vertical level is defined as the horizontal temperature gradient magnitude $|\partial T / \partial X|$, which was calculated using a Sobel operator. The Sobel operator calculates a temperature gradient magnitude by combining zonal and meridional components. The one exception is in the longitudinal cross sections of Fig. 2, where only the meridional component is used. To better capture the vertical extent of the AFZ, this calculation was performed at both 700 
and $500 \mathrm{hPa}$. As demonstrated by the thermal wind equation,

$$
\left(V_{g}\right)_{2}-\left(V_{g}\right)_{1}=\left(\frac{R}{f} \ln \frac{p_{1}}{p_{2}}\right) \mathbf{k} \times \nabla(\bar{T}),
$$

where $\left(V_{g}\right)_{1}$ and $\left(V_{g}\right)_{2}$ are the geostrophic wind at pressure levels $p_{1}$ and $p_{2}$, respectively, $R$ is the gas constant, $f$ is the Coriolis frequency, and $\bar{T}$ is temperature (averaged for the levels between $p_{1}$ and $p_{2}$ ), stronger horizontal temperature gradients lead to greater vertical wind shear and [as seen in Eq. (1)] greater baroclinic instability. Following Simmonds and Lim (2009), seasonal values of EGR and AFZ strength were obtained by first calculating these values for 6-h time steps and then taking an average.

\section{c. Cyclone detection}

Cyclone detection and tracking relies on an algorithm based on prior work by Serreze et al. (1993), Serreze (1995), and Serreze and Barrett (2008). Several features of more recent algorithms, especially by Wernli and Schwierz (2006) and Hanley and Caballero (2012), were also incorporated. The main innovation is explicit identification of multicenter cyclones and splitting and merging events, which have only previously been considered in a few algorithms (Inatsu 2009; Hanley and Caballero 2012).

The present study seeks to resolve relationships between the AFZ and cyclone characteristics over the Arctic Ocean, so SLP was chosen as the most appropriate variable for cyclone detection. This choice makes results more directly comparable to several prior Arctic studies (Serreze et al. 1993; Zhang et al. 2004; Serreze and Barrett 2008). Additionally, since synoptic-scale systems that cross into the Arctic Ocean are of chief interest, shortcomings of SLP methods related to small, weak systems (Sinclair 1994; Hodges et al. 2003) are not especially problematic. The one concern would be if erroneous conclusions about genesis areas resulted from late detection of cyclones (Neu et al. 2013; Rudeva et al. 2014).

MERRA SLP data are provided on a longitudelatitude grid, and this unequal spatial resolution will lead to biases in the density of cyclone centers detected at high latitudes (Sinclair 1997). Therefore, the SLP data were first reprojected using cubic convolution onto the Northern Hemisphere equal-area Special Sensor Microwave Imager (SSM/I) grid 2.0 [Equal-Area Scaleable Earth (EASE) Grid 2.0; Brodzik et al. 2012] with a gridcell size of $100 \mathrm{~km}$ by $100 \mathrm{~km}$. The EASE Grid 2.0 is based on a Lambert's equal-area azimuthal projection centered on $90^{\circ}$ latitude.
A problem with cyclone detection using SLP is that extrapolation of SLP from high-elevation areas often leads to artificial pressure minima (König et al. 1993; Serreze 1995). Following Neu et al. (2013) and Tilinina et al. (2013), all grid cells with an elevation exceeding $1500 \mathrm{~m}$ were masked before implementing the detection stage.

Cyclone detection involves three steps. First, local minima in SLP are identified as grid cells for which the pressure is lower than the eight adjacent grid cells. Second, following previous studies (e.g., Blender et al. 1997; Trigo et al. 1999), a strength parameter is applied. A circle with a $1000-\mathrm{km}$ radius is drawn around each minimum, and the average SLP difference between the minimum and each grid cell intersecting that circle is calculated. If the average SLP difference is less than $7.5 \mathrm{hPa}$ for a minimum, it is considered too weak to be a cyclone of interest and is discarded. The exact value of the parameter, which matches that used by Hanley and Caballero (2012), was determined from a series of sensitivity studies.

The final detection step simultaneously calculates cyclone area and determines the presence of multicenter cyclones (MCCs). This step is notable because it recognizes that 1) cyclones are not point features but areas and 2) a single system may contain two or more distinct but closely related minima in SLP. MCC detection is based on the method of Hanley and Caballero (2012), but the shared-to-unshared ratio is calculated using cyclone area enclosed by the last closed contour instead of the number of contours. (See section S1 of the supplementary material for details.)

\section{d. Cyclone tracking}

One benefit of using the MERRA 3-hourly fields is that, with average propagation speed lying between 10 and $60 \mathrm{~km} \mathrm{~h}^{-1}$ for most cyclones (Rudeva et al. 2014), cyclone propagation between each time interval is usually only one or two grid cells. This results in very few ambiguous tracking situations and permits a simple nearest-neighbor approach as the basis for tracking. Consider two fields of cyclone centers at times $t_{n}$ and $t_{n+1}$. To determine whether a cyclone center at $t_{n}$ also exists at $t_{n+1}$, continuing its track, a search radius of $450 \mathrm{~km}$ is used, corresponding to a maximum allowed propagation speed of $150 \mathrm{~km} \mathrm{~h}^{-1}$. The effective maximum propagation speed in previous algorithms has a broad range [cf. the $80 \mathrm{~km} \mathrm{~h}^{-1}$ used by Blender et al. (1997) with the $167 \mathrm{~km} \mathrm{~h}^{-1}$ used by Wernli and Schwierz (2006)], but Neu et al. (2013) comment that cyclones can move faster than $110 \mathrm{~km} \mathrm{~h}^{-1}$ in extreme cases. Therefore, $150 \mathrm{~km} \mathrm{~h}^{-1}$ was chosen as a reasonable round number.

A predicted location $\mathbf{x}^{*}$ is also incorporated for cyclone centers that have existed for multiple time steps. 
Following Wernli and Schwierz (2006) and Hanley and Caballero (2012), the predicted location $\mathbf{x}^{*}\left(t_{n+1}\right)$ is a reduced linear continuation of the cyclone's past propagation and calculated by the equation $\mathbf{x}^{*}\left(t_{n+1}\right)=$ $0.75\left[\mathbf{x}\left(t_{n}\right)-\mathbf{x}\left(t_{n-1}\right)\right]$, where $\mathbf{x}\left(t_{n}\right)$ is the cyclone's current location and $\mathbf{x}\left(t_{n-1}\right)$ was the cyclone's location at time $t_{n-1}$. The factor of 0.75 is included because the propagation speed of cyclones tends to decline with age. To be considered a continuation of a cyclone center from $t_{n}$, a center in $t_{n+1}$ must lie within $450 \mathrm{~km}$ of both $\mathbf{x}\left(t_{n}\right)$ and $\mathbf{x}^{*}\left(t_{n+1}\right)$. If multiple potential matches exist in $t_{n+1}$ for a single $t_{n}$ center, the nearest neighbor to the predicted location is chosen as the continuation.

After all matches have been made between the centers from $t_{n}$ and $t_{n+1}$, the occurrence of cyclone events is assessed, including cyclogenesis and cyclolysis. Cyclogenesis occurs if any center in $t_{n+1}$ has no corresponding center in $t_{n}$. Cyclolysis occurs if any center in $t_{n}$ has no corresponding center in $t_{n+1}$. A documented problem with simple SLP-based methods such as Serreze (1995) is unrealistic splitting of cyclone tracks into multiple parts (Mesquita et al. 2009). In this updated algorithm, the track of an MCC will continue if any of its centers persists, which reduces the likelihood that a cyclone's track will be split. (See section S2 of the supplementary material for details.)

\section{e. Cyclone characteristics}

The algorithm returns a large number of cyclone tracks, many of which consist of only a few time steps. Despite the elevation mask and strength parameter of $7.5 \mathrm{hPa}(1000 \mathrm{~km})^{-1}$, some detected centers are not synoptic-scale cyclones but heat lows or artifacts related to high elevation. To eliminate some of these unwanted features, only cyclones that last at least $24 \mathrm{~h}$ (8 time steps), travel at least $100 \mathrm{~km}$ ( 1 grid cell), and spend at least one time step over elevations lower than $500 \mathrm{~m}$ were retained. Additionally, only one track was used for each MCC when measuring average cyclone frequency and intensity for the study area. (However, this choice makes only minor differences to results; see section S1 and Figs. S4 and S5 of the supplementary material.)

Several cyclone characteristics are assessed, including frequency, intensity, and deepening rate. Following past research (e.g., Zolina and Gulev 2002; Hodges et al. 2011; Rudeva et al. 2014), all maps of cyclone characteristics have been smoothed. The value at any particular grid cell represents the average for a $500 \mathrm{~km}$ by $500 \mathrm{~km}$ area centered on that grid cell. Frequency is measured using track density, defined as the number of cyclone tracks passing through a $500 \mathrm{~km}$ by $500 \mathrm{~km}$ area centered on the grid cell for a given period. Similarly, the event density (genesis or lysis) is the number of events that occur in a $500 \mathrm{~km}$ by $500 \mathrm{~km}$ area for a given period.

Intensity is measured using both the cyclone central pressure and the Laplacian of the central pressure. The latter is often preferred because it is independent of latitude and proportional to geostrophic relative vorticity (e.g., Murray and Simmonds 1991; Serreze et al. 1997). The deepening rate is measured following Roebber (1989), Serreze et al. (1997), and others, as follows:

$$
\mathrm{DR}=\frac{d p}{d t} \frac{\sin 60^{\circ}}{\sin \phi}
$$

where DR is the deepening rate, $d p / d t$ is the change in central pressure over time, and $\phi$ is the latitude. This adjustment accounts for the change in the relationship between a unit pressure gradient and the geostrophic wind by latitude. The reference latitude is arbitrary, so $60^{\circ}$ was chosen to match Serreze et al. (1997).

An alternative approach is to calculate deepening rate as the change in relative SLP, or the central pressure of a cyclone minus the climatological pressure for its location at the same time of year (Lim and Simmonds 2002). This approach is useful when concerned with changes in deepening rate for cyclones passing through areas with greatly varying climatological pressures. The present study is narrowly focused on deepening in a confined area (the Siberian coast) and season (summer).

\section{f. Statistical analysis}

In addition to examining seasonal characteristics of AFZ strength with EGR and cyclone characteristics, several statistical analyses were performed. A tracklevel analysis was performed for all cyclone centers that crossed through the AFZ and into the combined CAO and BCEL study area (dark blue shading in Fig. 1; hereafter CAO+BCEL) for the summer season (JJA) over the period 1979-2014. The Barents and Kara Seas were omitted because they are primarily influenced by the North Atlantic storm track. For each track, the DR of a cyclone crossing the AFZ was described as follows:

$$
\begin{aligned}
\mathrm{DR}= & \alpha+\beta_{1} \frac{\mathrm{AGE}}{\mathrm{LIFESPAN}}+\beta_{2} \frac{\text { MPAGE }}{\text { LIFESPAN }} \\
& +\beta_{3}(\mathrm{AFZ})+\beta_{4}\left[\frac{\pi}{12} \sin \left(t_{\text {local }}+\sigma\right)\right]
\end{aligned}
$$

where AFZ is the average AFZ strength $(|\partial T / \partial X|$, described in section $2 b$ ) at the time of AFZ crossing for the group of five contiguous coastal grid cells centered on the point of AFZ crossing. Following the baroclinic instability model, strong horizontal temperature gradients at middle and upper levels of the troposphere are favorable for cyclone deepening $(\mathrm{DR}<0)$ because they 
lead to greater vertical shear [Eq. (2)] and therefore greater baroclinic instability [Eq. (1)].

However, other variables may also impact the deepening rate and must be controlled for to ensure that any resulting coefficients are physically meaningful. The first two variables describe a typical cyclone life cycle. AGE is the age of the cyclone at the time of AFZ crossing, MPAGE is the age of the cyclone when it experiences its minimum pressure, and LIFESPAN is the age of the cyclone when it experiences lysis. Cyclone age is included because cyclone deepening rate tends to be strongest (most negative) when a cyclone is just forming (Rudeva et al. 2014). The older a cyclone is at the point of AFZ crossing, the more likely it is to be filling instead of deepening. Since a cyclone begins filling (DR $>0$ ) after it hits its minimum pressure, stronger deepening might be expected during AFZ crossing if the cyclone has yet to reach its minimum pressure.

The final term represents the diurnal thermal atmospheric tide, an SLP oscillation in the summer Arctic driven by the sensible heat flux from the ground (Dai and Wang 1999; see Fig. S6 in the supplementary material). In Eq. (4), $t_{\text {local }}$ is the local time of day, and $\sigma$ is the phase ( $9 \mathrm{~h}$, determined empirically). The null hypothesis is that, after controlling for the relative age of the cyclone at AFZ crossing, relative age at its point of minimum pressure, and the diurnal cycle of SLP enforced by the thermal tide, the temperature gradient magnitude during AFZ crossing has no impact on the deepening rate (i.e., $\beta_{3}=0$ ).

In addition to considering the significance of coefficients, models were assessed using the variance inflation factor for multicollinearity among right-hand variables, Cook's distance for outliers, histograms and quantile-quantile (Q-Q) plots for normality of residuals, and the Breuch-Pagan test for heteroskedasticity of residuals.

Last, correlations were calculated between overall AFZ strength and EGR along the Arctic coastline and between AFZ strength and cyclone intensity in the $\mathrm{CAO}+\mathrm{BCEL}$ for the summer season over the period 1979-2014. Correlations were calculated both before and after subtracting the linear relationship between SVNAM and the other variables. Pearson's correlations were used because Shapiro-Wilks tests revealed no significant difference from a normal distribution for any variable. All statistical analyses were performed separately using AFZ strength at both 700 and $500 \mathrm{hPa}$.

\section{Results}

\section{a. The AFZ and baroclinic instability}

Prior studies (e.g., Reed and Kunkel 1960; Serreze et al. 2001; Serreze and Barrett 2008) argue that baroclinicity in the troposphere induced by differential heating of adjacent land and ocean surfaces in the Arctic may help to generate cyclones that impact the Arctic Ocean. Figure 2 shows latitudinal cross sections of the meridional temperature gradient (Figs. 2a,b) and vertical velocity (Figs. 2c,d) for January and July along the $151^{\circ} \mathrm{E}$ meridian, a longitude typical of the AFZ. [See Crawford and Serreze (2015) for cross sections along other longitudes.] In winter, the only substantial meridional temperature gradients above the surface level are around $30^{\circ} \mathrm{N}$. However, in summer, two distinct frontal zones are apparent extending from the surface to the tropopause. The polar front sits at about $40^{\circ} \mathrm{N}$, but north of and distinct from that zone lies the AFZ, which is anchored to the coastline. Contribution by surface energy fluxes to the coastal temperature gradients aloft is supported by the presence of upward (negative) vertical velocity (omega) just south of the coastline.

From the thermal wind equation [Eq. (2)], strong horizontal temperature gradients throughout the troposphere create vertical wind shear, which is a major component in the calculation of maximum EGR [Eq. (1)]. In winter, when the polar front is strongest and the AFZ is absent, EGRs in excess of 1.0 day $^{-1}$ are common around the Icelandic low and the Canadian Rockies (Fig. 2e). While all the relative maxima in EGR lie in the midlatitudes, the coastline of Siberia is a relative minimum.

In summer, the strength of the polar front is greatly reduced, as are EGRs in the Icelandic low region (Fig. 2f). The Eurasian coastline, on the other hand, experiences higher EGRs in summer and is a relative maximum during that season. In other words, the presence of the summer AFZ supports a region of baroclinic instability. Following the baroclinic instability model of cyclone development, the AFZ environment seems to favor cyclone development along the Eurasian Arctic coastline.

\section{b. Cyclone characteristics}

Figure 2 demonstrates that the AFZ is favorable for cyclone development, but is it actually a preferred region of summer cyclogenesis? Figure 3 shows the average track density (Figs. 3a,b), cyclogenesis frequency (Figs. 3c,d), and cyclolysis frequency (Figs. 3e,f) for winter and summer seasons 1979-2014. Cyclone frequency is greater in winter (Fig. 3a) than summer (Fig. 3b) on the Atlantic side of the Arctic and Gulf of Alaska. By contrast, activity over the CAO and eastern Siberia is notably higher in the summer season.

Cyclogenesis shows similar seasonal differences. In winter, a broad area of cyclogenesis extends from the Icelandic low to the Norwegian and Barents Sea. Cyclogenesis is also common in the lee of the Rockies and 


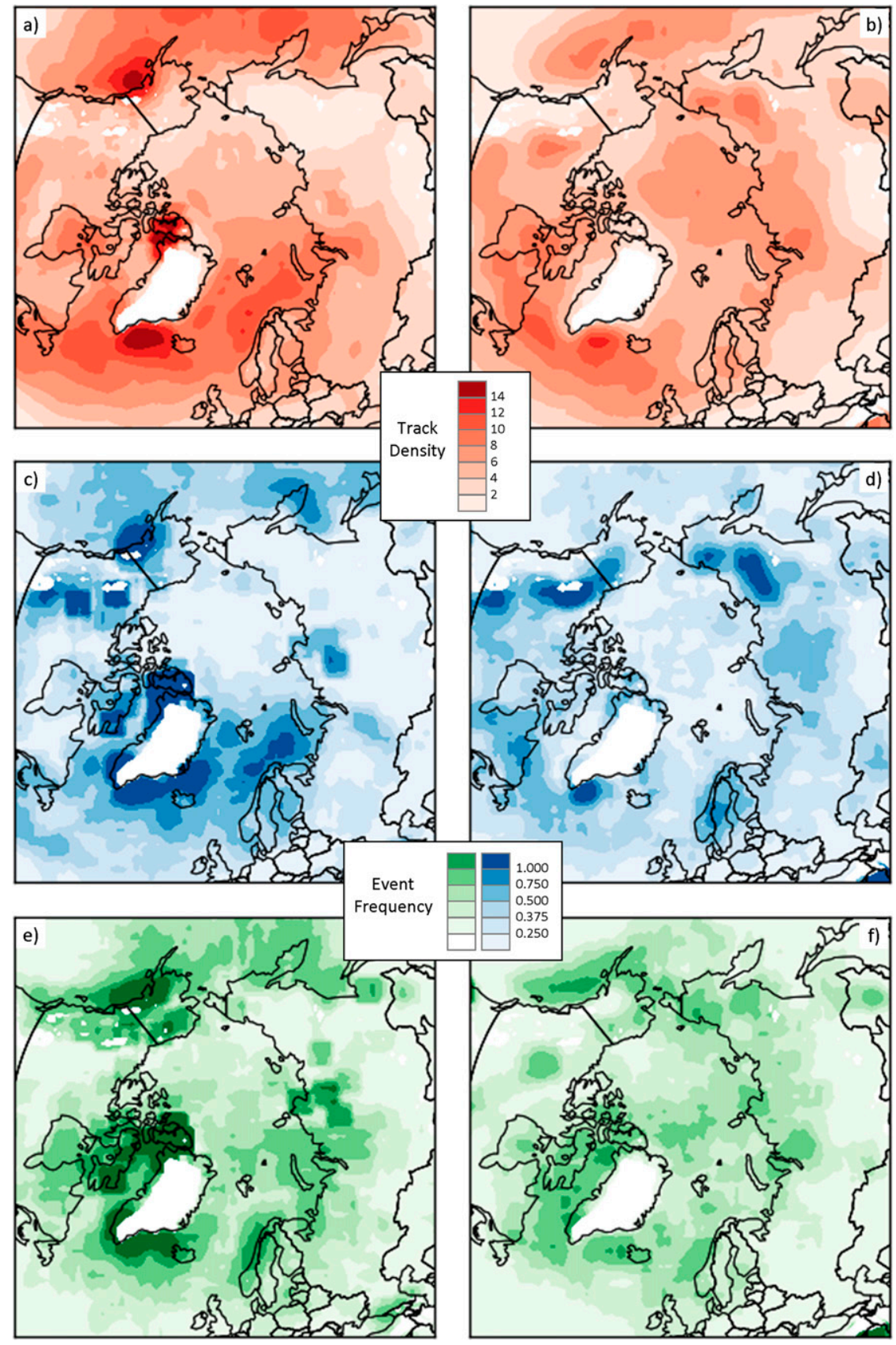

FIG. 3. Frequency of (a),(b) cyclone tracks, (c),(d) cyclogenesis events, and (e),(f) cyclolysis events for (a),(c),(e) winter (DJF) and (b),(d),(f) summer (JJA), averaged for the period 19792014. Units are the number of tracks or events per $500 \mathrm{~km}^{2}$ area per month.

Greenland and in northern Baffin Bay. Last, cyclogenesis is common in southern Kamchatka and in the Gulf of Alaska. The prominence of the Icelandic low and Norwegian and Barents Seas as cyclogenesis regions is reduced in summer, while the relative importance of continental cyclogenesis is increased. Eastern Siberia is particularly notable in this regard. It contains a strong maximum in summer cyclogenesis in the Kolyma lowland (see Fig. 1). The AFZ, however, is not a preferred area for summer cyclogenesis.

For both winter and summer, many of the regions experiencing frequent cyclogenesis also experience frequent cyclolysis, such as the Icelandic low and the Gulf of Alaska. Other regions exhibit more cyclogenesis than 
cyclolysis. In winter, these include the Norwegian and Barents Seas and the lee of the Rockies in the United States and Alberta (see also Fig. S5). In summer, the strongest net genesis regions are the Kolyma lowland and the lee of the Rockies. The CAO+BCEL is distinct because it does not exhibit substantial cyclogenesis in either season, but it is consistently an area for cyclolysis. This quality is especially apparent in summer when cyclone frequency in the $\mathrm{CAO}+\mathrm{BCEL}$ increases.

\section{c. Source regions for summer Arctic Ocean cyclones}

One notable finding from Fig. 3 is that although the AFZ may be a favorable environment for cyclone development, it is not a preferred region of summer cyclogenesis. Where, then, do cyclones affecting the $\mathrm{CAO}+\mathrm{BCEL}$ originate? The genesis region for every cyclone that spends any part of its life span in the $\mathrm{CAO}+\mathrm{BCEL}$ is recorded in Fig. 4. In both winter and summer, $35 \%-40 \%$ of all cyclones that enter the $\mathrm{CAO}+\mathrm{BCEL}$ originate locally [including the "arctic cyclones" described by Tanaka et al. (2012)]. About the same number of cyclones enter the $\mathrm{CAO}+\mathrm{BCEL}$ from elsewhere in each season, but the source regions change substantially. The North American, Pacific, and Atlantic regions all contribute more cyclones in winter. By contrast, the Asian region contributes many more cyclones in summer and accounts for more than half of all externally sourced summer cyclones that enter the $\mathrm{CAO}+\mathrm{BCEL}$.

These results complement Fig. 3, which showed substantially more cyclogenesis over the Eurasian continent in summer than winter, especially around the Kolyma lowland and the Putorana Plateau (PP in Fig. 1). Focusing on the former, Fig. 5 shows the tracks (Figs. 5a,b) and track density (Figs. 5c,d) for all cyclones originating in region B of Fig. 4 for winter and summer. Few cyclones form here in winter, and on average only one or two cyclones migrate into the $\mathrm{CAO}+\mathrm{BCEL}$ each winter. By contrast, the average summer includes 5-7 storms that form in this region and migrate into the $\mathrm{CAO}+\mathrm{BCEL}$ and another one to three that track eastward into the Pacific Ocean. The greatest track density in summer lies in the Kolyma lowland and along the northeast edge of the Siberian mountains.

The algorithm points to central Siberia (Fig. 6a, or region $\mathrm{C}$ in Fig. 4), especially around the Putorana Plateau, as another summer source region for the $\mathrm{CAO}+\mathrm{BCEL}$. Cyclogenesis in this region is less pronounced and more diffuse than in eastern Siberia, where the focus is clearly to the northeast of the Siberian mountains. Cyclones track from central Siberia in several directions, although they again most often move northward and/or eastward. One particularly populous a)

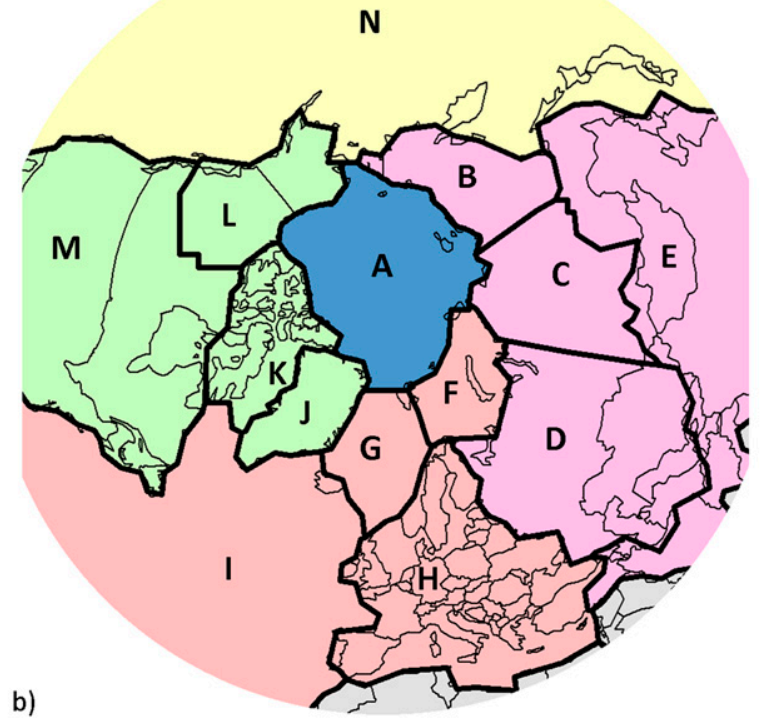

\begin{tabular}{|l|r|r|r|r|}
\hline Genesis Regions & DJF & $\%$ & JJA & $\%$ \\
\hline All & 1614 & 100.0 & 1583 & 100.0 \\
\hline A: CAO + BCEL Seas (Local) & 679 & 42.1 & 582 & 36.8 \\
\hline Asian Region & 158 & 9.8 & 522 & 33.0 \\
\hline B: Eastern Siberia \& Chukotka & 86 & 5.3 & 202 & 12.8 \\
C: Central Siberia & 47 & 2.9 & 178 & 11.2 \\
D: Western Russia & 24 & 1.5 & 119 & 7.5 \\
E: Southern Asia & 1 & 0.1 & 23 & 1.5 \\
\hline Atlantic/European Region & 375 & 23.2 & 217 & 13.7 \\
\hline F: Barents \& Kara Seas & 122 & 7.6 & 105 & 6.6 \\
G: Greenland \& Norwegian Seas & 184 & 11.4 & 59 & 3.7 \\
H: Europe & 17 & 1.1 & 34 & 2.2 \\
I: North Atlantic Ocean & 52 & 3.2 & 19 & 1.2 \\
\hline North American Region & 276 & 17.1 & 196 & 12.4 \\
\hline J: Greenland & 108 & 6.7 & 65 & 4.1 \\
K: Canadian Arctic Archipelago & 80 & 5.0 & 45 & 2.8 \\
L: North Rockies/Brooks Range & 80 & 5.0 & 80 & 5.1 \\
M: South/East North America & 8 & 0.5 & 6 & 0.4 \\
\hline N: Pacific Region & 126 & 7.8 & 66 & 4.2 \\
\hline
\end{tabular}

FIG. 4. Distribution of cyclones entering the CAO and BCEL for winter (DJF) and summer (JJA) 1979-2014. (a) Map showing 14 source regions (A through $\mathrm{N}$ ) for $\mathrm{CAO}+\mathrm{BCEL}$ cyclones. (b) Table showing the quantity and percentage of cyclones originating in each region.

track is across the Lena River delta and over the Laptev Sea.

While the Siberian region is a significant source of summer cyclones for the CAO+BCEL, the prominent genesis region east of the Mackenzie Range in Canada is only a minor source. Whereas about a third of the detected cyclones forming over the Siberian regions eventually travel into the CAO+BCEL, only $13 \%$ of those forming in the northwest corner of North America 

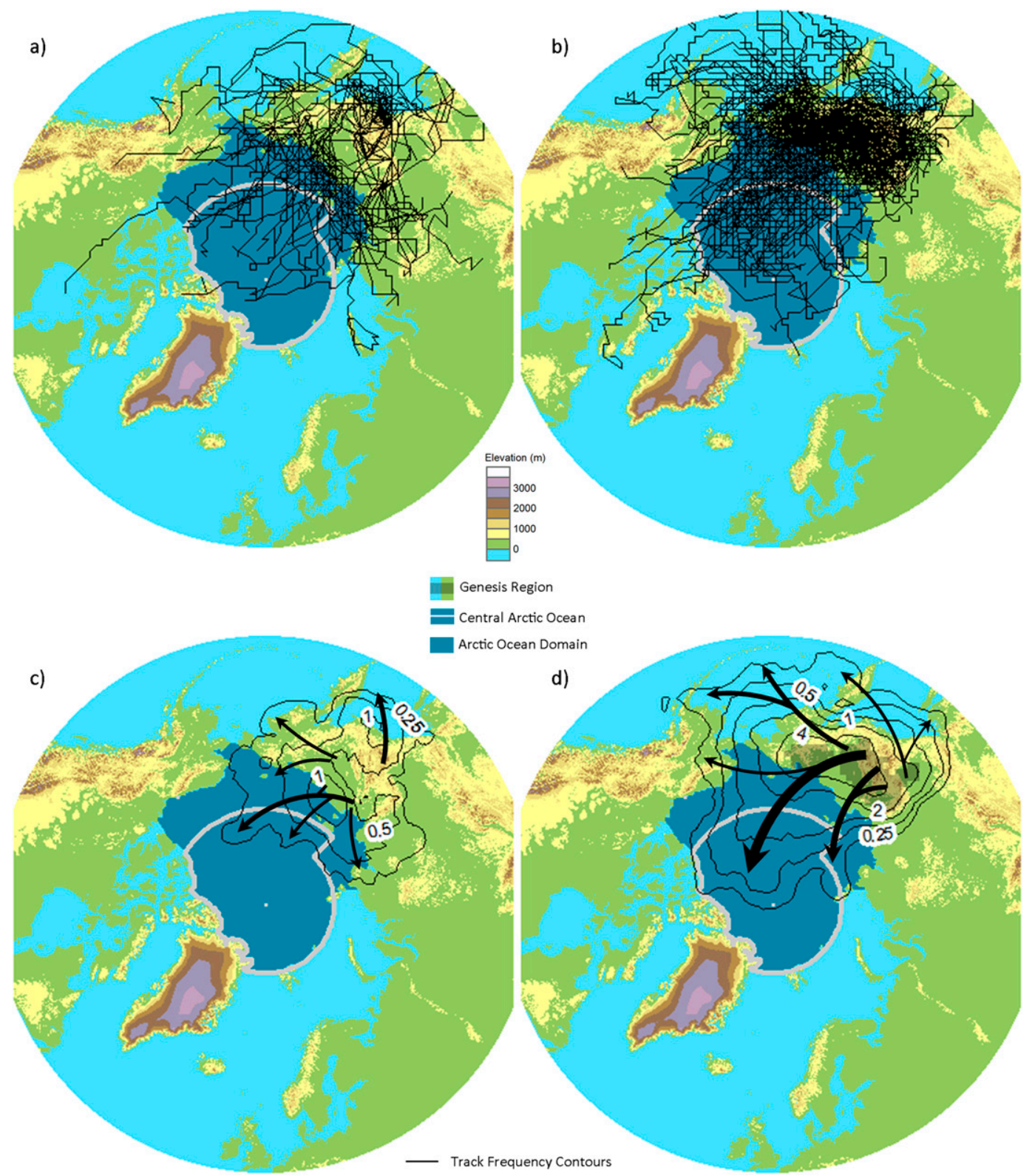

FIG. 5. (a),(b) Spaghetti plots and (c),(d) contour plots of cyclone tracks [tracks (month) ${ }^{-1}$ ] originating in eastern Siberia (region B in Fig. 4) during (a),(c) winter (DJF) and (b),(d) summer (JJA) 1979-2014. Shaded regions on average have more than 1.5 genesis events every season.

(region L in Fig. 4) ever do. This region also lacks the seasonal contrasts observed in Siberia; it contributed exactly 80 cyclones to the CAO+BCEL during the study period in both winter and summer. As seen in Fig. 6b, this is largely because a majority of Mackenzie cyclones track southeastward across the Canadian Shield.

One final observation from Figs. 5 and $6 \mathrm{a}$ is that all of the cyclones that migrate from Siberia to the Arctic Ocean pass over the AFZ. Indeed, to reach the $\mathrm{CAO}+\mathrm{BCEL}$, nearly all of the 522 systems generated over Asia, and many of those generated over the Pacific Ocean, western North America, and Europe, pass through the AFZ. In total, 764 cyclones over 36 years make the passage, which accounts for the majority of cyclones that migrate into the CAO+BCEL. This presents a new possibility: because of its strong baroclinicity, the AFZ may be an area where preexisting cyclones experience additional deepening. This idea was explored using multiple statistical analyses whose results are presented below. 


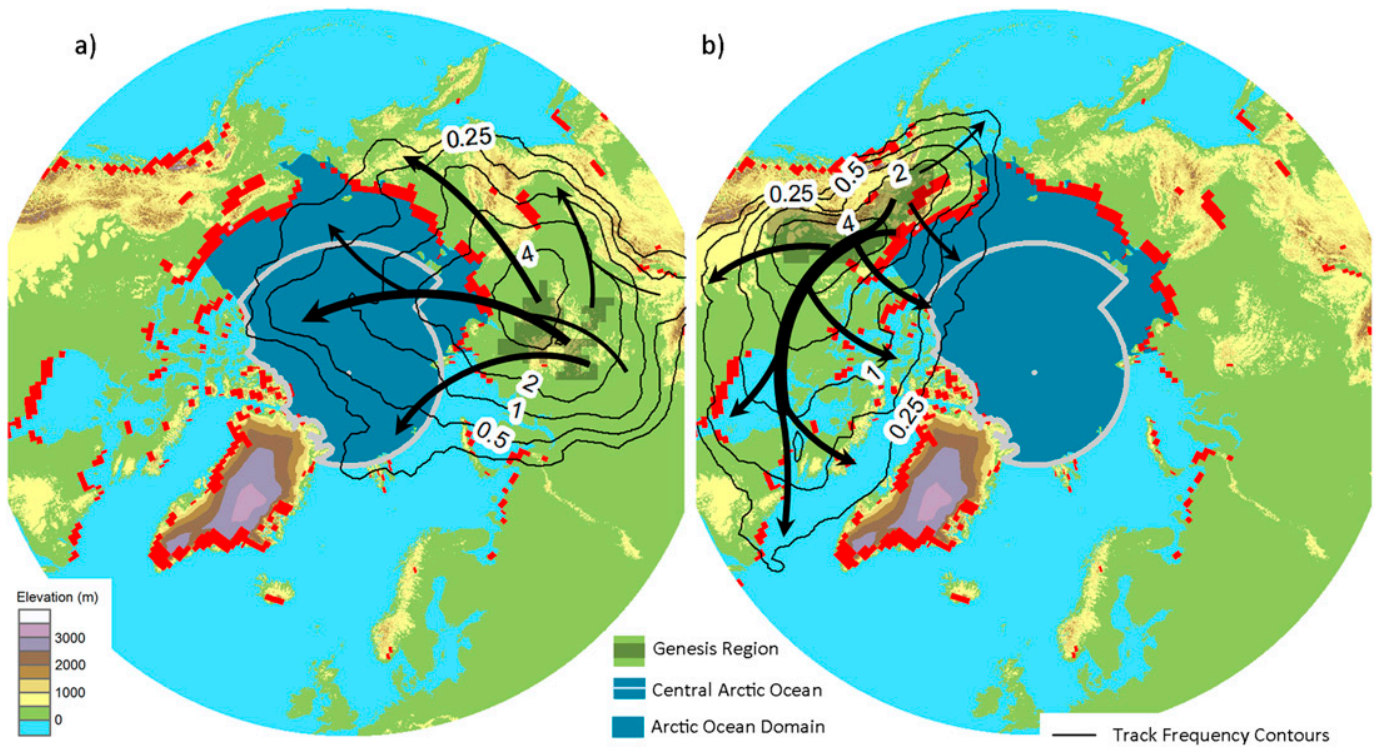

FIG. 6. Contour plots of cyclone tracks [tracks (month) ${ }^{-1}$ ] originating in (a) central Siberia (region C in Fig. 4) and (b) northwestern North America (region L) during summer (JJA) 1979-2014. Shaded regions on average have more than 1.5 genesis events every season.

\section{d. Track-by-track analysis of Arctic cyclone deepening/filling rate}

Of the 764 summer cyclones that crossed the Arctic coastline on their way to the CAO+BCEL from 1979 to 2014,540 of them spent at least one time step in a coastal grid cell. For winter, the counts are 539 and 315, respectively. The AFZ is only present in summer, so if it acts as a cyclone intensifier, then cyclones crossing the coastline in summer should experience more deepening (or less filling) than those crossing in winter. On average, summer cyclones experience a weak deepening rate of $-0.4 \mathrm{hPa} \mathrm{day}^{-1}$ when crossing the coastline, whereas winter cyclones experience a filling rate of $+6.7 \mathrm{hPa} \mathrm{day}^{-1}$. The difference is significantly different from zero with a $99 \%$ confidence interval using a two-sample Wilcoxon rank test. Because of different source regions, winter cyclones in this comparison tend to be slightly older than summer cyclones. However, the difference remains significant at the $99 \%$ confidence level after controlling for the relative age at crossing. Therefore, this test is preliminary evidence that cyclones are likely to fill less rapidly (or even deepen) during coastline passage when the AFZ is present.

If the baroclinicity of the AFZ is truly the cause of this relationship, then day-to-day variations in AFZ strength should also influence the deepening rate of cyclones passing through it. The subset of 540 summer cyclones was examined more closely using the regression analysis described in section $2 \mathrm{f}$. The null hypothesis is that, after controlling for other cyclone life cycle characteristics and time of day, AFZ strength at the given level will have no impact on the deepening rate of cyclones as they cross the Arctic Ocean coastline.

The estimated coefficients for each regression model are presented in Table 1 . Note that since deepening occurs when the central pressure drops, a negative coefficient means that an increase in the right-hand variable is associated with greater deepening (or less filling). Conversely, a positive coefficient indicates that an increase in the right-hand variable is associated with less deepening (or greater filling). As expected, a positive relationship exists between the relative age of a cyclone and its deepening rate, meaning that cyclones have a tendency to deepen less vigorously as they age. After reaching its minimum pressure, a cyclone will begin to fill, so if the minimum is experienced before the cyclone crosses the AFZ, the cyclone is more likely to experience filling during the crossing. On the other hand, if the minimum is experienced after the cyclone crosses the AFZ, the cyclone is more likely to experience deepening during the crossing. This yields a negative relationship; the later the occurrence of minimum pressure, the stronger the deepening rate should be during AFZ crossing. These two relationships are significant regardless which vertical level is used to measure AFZ strength.

Also significant is the local time of day. The positive coefficient indicates that a cyclone's central pressure is expected to fall from about 2100 to $0900 \mathrm{LT}$ and rise 
TABLE 1. Coefficients ( \pm 1.96 standard error) for multiple linear regression models [Eq. (3)] describing the deepening rate of cyclones as they pass through the AFZ during June, July, and August. AFZ strength was measured at both 700 and 500 hPa, so two models were constructed, one for each measure of AFZ strength. Significance is denoted at $p<0.05$ using boldface text and at $p<0.01$ using italics.

\begin{tabular}{clcrr}
\hline \hline Variable & \multicolumn{1}{c}{ Description } & Units & $700 \mathrm{hPa}$ & \multicolumn{1}{c}{$500 \mathrm{hPa}$} \\
\hline$\beta_{1}$ & Relative age at AFZ crossing & - & $+17.50 \pm 2.91$ & $+17.63 \pm 2.89$ \\
$\beta_{2}$ & Relative age at minimum pressure & - & $-11.19 \pm 2.83$ & $-11.49 \pm 2.81$ \\
$\beta_{3}$ & AFZ strength at AFZ crossing & $\mathrm{K}(100 \mathrm{~km})^{-1}$ & $-\mathbf{2 . 1 0} \pm \mathbf{1 . 6 1}$ & $-2.30 \pm 1.70$ \\
$\beta_{4}$ & Diurnal oscillation of thermal atmospheric tide & $\mathrm{h}$ & $\mathbf{+ 1 . 1 6} \pm \mathbf{0 . 9 9}$ & $+\mathbf{1 . 1 0} \pm \mathbf{1 . 0 0}$ \\
$\alpha$ & Intercept & $\mathrm{hPa} \mathrm{day}^{-1}$ & $+1.14 \pm 2.76$ & $+1.27 \pm 2.77$ \\
\hline
\end{tabular}

from 0900 to $2100 \mathrm{LT}$, similar to findings by Dai and Wang (1999) that the diurnal tide over Siberia in summer peaks in the midmorning.

Finally, in both models, the null hypothesis that the AFZ strength has no impact on cyclone deepening rates after controlling for cyclone life stage and time of day can be rejected. The variable for AFZ strength has a significant negative coefficient, meaning that stronger temperature gradients at midtropospheric levels are associated with less filling (or greater deepening) of cyclones crossing the coastline. The AFZ strength variable also remains significant for both 700 and $500 \mathrm{hPa}$ if any one, any two, or all other right-hand variables are removed from the model.

These models explain a small but significant $29.4 \%$ (for $700 \mathrm{hPa}$ ) or $29.6 \%$ (for $500 \mathrm{hPa}$ ) of the variance in cyclone deepening rate. Multicollinearity among righthand variables is minimal, with the highest variance inflation factor under 1.04 for each model. The residuals in both models follow closely with a normal distribution, and no single observation was a major outlier. However, in the 700-hPa model, there may be some concern for heteroskedasticity in residuals (see Fig. S7 in the supplementary material).

\section{e. Seasonal analysis of Arctic cyclone intensity}

If, as the previous results suggest, the AFZ at midtropospheric levels is a cyclone intensifier, then it might also be expected to exhibit some relationship with aggregate cyclone characteristics in the Arctic Ocean for each summer season. Table 2 shows the correlation between AFZ strength (at either 700 or $500 \mathrm{hPa}$ ) and average cyclone intensity (central SLP and its Laplacian) in the CAO+BCEL. It also shows the correlation between AFZ strength and EGR at $500 \mathrm{hPa}$ throughout the AFZ.

Consistent with Eqs. (1) and (2), a strong positive relationship is observed between AFZ strength at $500 \mathrm{hPa}$ and EGR at $500 \mathrm{hPa}$. The correlation is weaker but also positive for the AFZ at $700 \mathrm{hPa}$. These results complement results in Fig. 2, which show the collocation of the AFZ and high EGR along the Siberian coast.
Comparing to the two measures of cyclone intensity, however, only the correlations with AFZ strength at $700 \mathrm{hPa}$ are significant. At this level, the temperature gradient magnitude has a modest but significant negative correlation with central SLP and a positive correlation with the Laplacian, meaning that when the AFZ is stronger at midtropospheric levels, cyclones in the Arctic Ocean are more intense than normal. This is consistent with the idea presented in the previous section; when the AFZ is stronger at midtropospheric levels, cyclones passing through it experience less weakening (or more strengthening). However, the 500-hPa level shows no support for AFZ intensification of cyclones.

A caveat of these correlations is that they do not take into account potential confounding factors like largescale circulation patterns. Particular concern lies with the SVNAM. Ogi et al. (2004) note a positive correlation between the SVNAM index and AFZ strength, and Serreze and Barrett (2008) describe a positive correlation between the SVNAM index and cyclone frequency in the CAO. Therefore, large-scale circulation may influence both the AFZ and cyclone activity, so correlations were also computed after subtracting the linear relationship with the SVNAM index for each variable. Results (Table 3) show that although the correlations between AFZ strength and EGR are robust to this modification, the relationship between AFZ strength and cyclone intensity is notably weakened. In fact, the correlation is only still significant for the Laplacian of central pressure.

TABLE 2. Pearson's correlations between AFZ strength and average cyclone central pressure and Laplacian of cyclone central pressure for cyclone centers in the $\mathrm{CAO}+\mathrm{BCEL}$ and EGR at $500 \mathrm{hPa}$ along the AFZ for all summers (JJA) 1979-2011. Correlations were conducted using AFZ strength at 700 and $500 \mathrm{hPa}$. Significance is denoted at $p<0.05$ using boldface text and at $p<$ 0.01 using italics.

\begin{tabular}{lcc}
\hline \hline \multicolumn{1}{c}{ Vertical level } & $700 \mathrm{hPa}$ & $500 \mathrm{hPa}$ \\
\hline Central SLP & $\mathbf{- 0 . 3 3 5}$ & -0.235 \\
Laplacian of central SLP & +0.510 & +0.216 \\
EGR at 500 hPa & +0.492 & +0.598 \\
\hline
\end{tabular}


TABLE 3. As in Table 2, but with the effect of SVNAM removed from variables using a linear model. Significance is denoted at $p<$ 0.05 using boldface text and at $p<0.01$ using italics.

\begin{tabular}{lcc}
\hline \multicolumn{1}{c}{ Vertical level } & $700 \mathrm{hPa}$ & $500 \mathrm{hPa}$ \\
\hline Central SLP & -0.235 & -0.234 \\
Laplacian of central SLP & $\mathbf{+ 0 . 4 0 8}$ & +0.148 \\
EGR at 500 hPa & +0.480 & +0.607 \\
\hline
\end{tabular}

\section{Discussion}

\section{a. General cyclone characteristics}

Conclusions from this study rest in part on the validity of the cyclone detection and tracking algorithm. The general results from this updated algorithm (Fig. 3) compare well to other published algorithms (see also section S3 in the supplementary material). Consistent with prior studies (e.g., Serreze 1995; Wernli and Schwierz 2006; Simmonds et al. 2008), cyclone frequency is greater in winter (Fig. 3a) than summer (Fig. 3b) on the Atlantic side of the Arctic and Gulf of Alaska. By contrast, activity over the CAO and eastern Siberia is notably higher in the summer season.

Patterns of cyclogenesis (Figs. 3c,d) and cyclolysis (Figs. $3 \mathrm{e}, \mathrm{f}$ ) are also similar to those identified in prior studies (e.g., Trigo 2006; Wernli and Schwierz 2006; Simmonds et al. 2008; Hanley and Caballero 2012). Decreased prominence of the Icelandic low region, the Norwegian Sea, and the Barents Sea as areas of cyclogenesis in summer was also noted by Whittaker and Horn (1984), Serreze (1995), and Simmonds et al. (2008). While the polar front weakens and its attendant cyclone activity slackens in summer, cyclogenesis over the continents increases. In part, this may be linked to radiative and turbulent heat fluxes from the warmer continent heating the overlying atmosphere, reducing stability (Serreze et al. 1992), but the areas of greatest continental cyclogenesis in Fig. 3 appear in the lee of mountain ranges. Last, the role of the $\mathrm{CAO}+\mathrm{BCEL}$ as a cyclone collection area, experiencing much lysis but little genesis, has also been noted in several studies (e.g., Reed and Kunkel 1960; Whittaker and Horn 1984; Serreze and Barrett 2008).

A feature in Fig. 3 not shared by all algorithms is frequent winter cyclogenesis in the Gulf of Alaska. The Gulf of Alaska lies at the end of the North Pacific storm track (Sinclair 1997; Gulev et al. 2001), so it might be expected to be dominated by cyclolysis. Indeed, even though cyclogenesis is also common according to the present algorithm, cyclolysis occurs more frequently in the Gulf of Alaska than cyclogenesis (Fig. S5). Studies using SLP or the Laplacian of SLP (e.g., Gulev et al. 2001; Pinto et al. 2005; Wernli and Schwierz 2006) similarly show some cyclogenesis but more cyclolysis in this area, but some studies using low-level vorticity (e.g., Sinclair 1997; Hoskins and Hodges 2002) show only cyclolysis. Gulev et al. (2001) commented on the difficulty of tracking systems that stagnate when entering this area. In the updated algorithm used here, stagnation of mature systems is often accompanied by splitting events, when a cyclone, most often an MCC, divides into two separate systems before its demise. These events account for more than half of the occurrences of winter cyclogenesis in the Gulf of Alaska and may not be readily captured in algorithms without detection of MCCs.

Another issue is the high track density and frequent summer cyclogenesis in the Kolyma lowland, to the north and east of the Siberian mountains. This feature has been noted in many past studies using multiple methods (Whittaker and Horn 1984; Serreze 1995; Sorteberg and Kvingedal 2006; Wernli and Schwierz 2006; Raible et al. 2008; Simmonds et al. 2008), although Mesquita et al. (2008) did not find such a feature. Cyclones forming north and east of the Siberian mountains are likely the result of lee cyclogenesis. The Verkhoyanski Mountain range especially is often perpendicular to airflow on the downwind side of the Urals trough, placing the Kolyma lowland in an area of frequent divergence aloft. This was noted by Serreze and Barrett (2008) and is also apparent in Fig. 7, which shows the mean summer 500-hPa GPH field, as well as the mean field when summer cyclogenesis is occurring north and east of the Siberian mountains. The trough in $500-\mathrm{hPa} \mathrm{GPH}$ over central Siberia is normally broad and weak, but airflow is generally west to east across the Verkhoyanski Mountain range. When cyclogenesis occurs, the trough is tighter and stronger, shifted eastward, and includes a south-north component in the contours. That region B in Fig. 4 generates the most summer cyclones in the Asian sector despite having the smallest area may reflect the combined impacts of these mountain ranges lying across a favorable area of midlevel flow.

As for cyclogenesis in the AFZ, the results presented here run counter to Serreze et al. (2001). Because they were using data with a coarser spatial resolution, Serreze et al. (2001) could not clearly distinguish between cyclogenesis along the AFZ and cyclogenesis farther inland, such as in the Kolyma lowland (in the lee of the Siberian mountains). Past research has shown that cyclone detection using vorticity may lead to earlier detection of some cyclones (Mesquita et al. 2009; Neu et al. 2013; Rudeva et al. 2014); however, since the relevant summer cyclogenesis maxima identified here lie to the south of the AFZ and their cyclones then track northeast, any shift in cyclogenesis regions resulting 


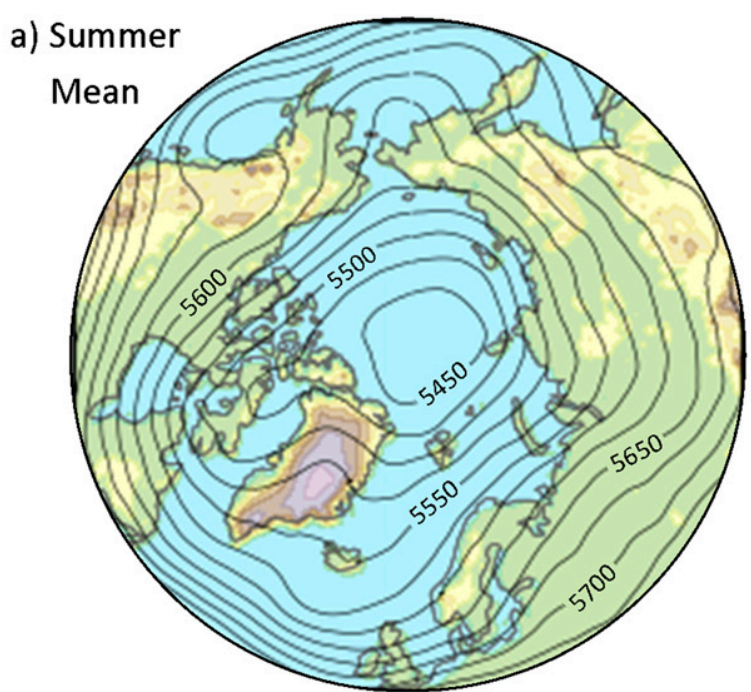

b) Siberian Lee

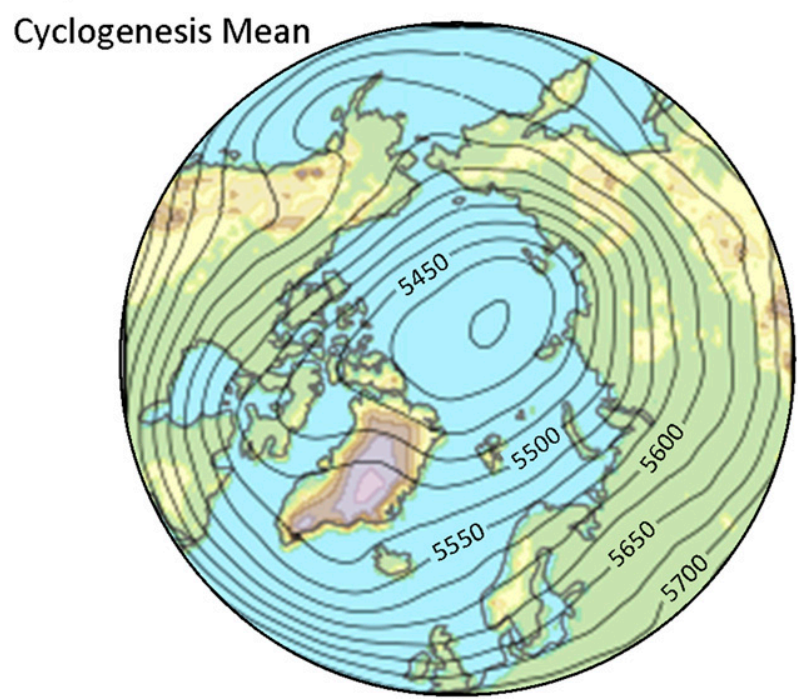

FIG. 7. (a) Mean summer GPH at $500 \mathrm{hPa}(\mathrm{m})$ for 1979-2014 and (b) mean $\mathrm{GPH}$ at $500 \mathrm{hPa}(\mathrm{m})$ for all instances of summer cyclogenesis in the Kolyma lowland.

from the implementation of a vorticity-based method would likely move the cyclogenesis even farther from the AFZ.

\section{b. The AFZ as cyclone intensifier}

While the AFZ is not a cyclone generator, the statistical tests described in section 3 indicate that it acts as a modest intensifier of storms crossing the Arctic Ocean coastline. However, it is difficult to determine just how important the AFZ really is. The greatest source of ambiguity is arguably the relationship between the AFZ and large-scale circulation. Past research has reported positive correlations between the SVNAM index and both AFZ strength (Ogi et al. 2004) and cyclone activity in the CAO (Serreze and Barrett 2008). Therefore, large-scale circulation may influence both the AFZ and cyclone activity. However, the cause and effect may also be reversed. Ogi et al. (2004) concluded that a stronger AFZ could favor the positive mode of the SVNAM. Additionally, results from Serreze et al. (2001), Ogi et al. (2004), and Crawford and Serreze (2015) all show that stronger zonal winds aloft (e.g., at $300 \mathrm{hPa}$ ) are related to a strong AFZ, so the formation of a strong circumpolar vortex in positive SVNAM years may be encouraged by the presence of a strong AFZ. Based on Serreze and Barrett (2008), this could mean that the AFZ also has an indirect connection to cyclone development through its influence on large-scale circulation. Furthermore, if the AFZ can be considered a forcing on large-scale circulation, then controlling for the SVNAM index in correlations may not be appropriate when assessing the link between the AFZ and cyclone activity.

Similarly, some ambiguity exists in the regression models built to compare AFZ strength and the deepening rate of individual systems. The AFZ is not responsible for generating the systems that it affects, and any cyclone that passes through the AFZ will have a cycle of deepening and filling independent of the AFZ. For instance, typical of extratropical cyclones, the storms generated in the lee of the Siberian mountains are associated with divergence aloft downstream of the trough axis in the 500-hPa GPH contours. Therefore, the AFZ is a secondary forcing operating in addition to the general life cycle of these storms. Accordingly, the most important predictors for cyclone deepening rate were cyclone age and the age at which minimum pressure is reached. These variables implicitly link back to the long wave troughs that drive cyclone development. Additionally, the variance in deepening rate explained by the regression models is modest (around 30\%), as is the correlation between AFZ strength and cyclone intensity ( $r$ being either 0.51 for the Laplacian of central pressure and the AFZ at $700 \mathrm{hPa}$ or 0.41 after controlling for the SVNAM index).

Examination of the AFZ-cyclone relationships could be improved in several ways, such as explicitly including upper-level divergence rather than implicitly including it by using measures of a cyclone's life cycle. Using a broader coastal width to define the AFZ might allow a larger population of cyclones to be examined. The relationship may also be explored using the regional- or cyclone-scale Lorenz energy box paradigm (Pezza et al. 2010). Finally, one caution with these results is that although historically the AFZ has been most often discussed in terms of its surface expression, that surface 
expression is only relevant to cyclone development insofar as thermal contrasts between land and ocean surfaces are translated to higher levels of the troposphere (see section S8 in the supplementary material).

\section{Conclusions}

Past studies have proposed a relationship between development of the summer AFZ along the Arctic coastline and the summer maximum in cyclone activity over the central Arctic Ocean (Dzerdzeevskii 1945; Reed and Kunkel 1960; Serreze et al. 2001), but the present study is the first to rigorously address this issue. High EGRs along the coast indicate that the AFZ has the potential to affect cyclone development, but contrary to previous arguments, the summer AFZ is actually not a cyclone generator. Instead, it acts as an intensifier. Many of the cyclones generated over Eurasia travel northeastward toward the Arctic Ocean and cross the AFZ along the way. When the AFZ is strong at midtropospheric levels, cyclones passing through it experience less filling (or more deepening). At the seasonal scale, a stronger AFZ at $700 \mathrm{hPa}$ is also associated with higher EGR and greater cyclone intensity in the $\mathrm{CAO}+\mathrm{BCEL}$.

The connection between the AFZ and cyclone development is hence more nuanced than envisioned by previous studies. This is particularly true of eastern Siberia, where several geological coincidences converge to promote cyclone development, including an L-shaped set of mountain ranges, apparently ideally oriented to intersect the frequent troughs east of the Urals, and a zonally oriented coastline lying just to the north that fosters baroclinicity. However, the confluence of topographic features with circulation patterns (as represented by the SVNAM index), along with the capacity for cyclone activity to in turn influence the surface expression of the AFZ, makes observational data alone insufficient to separate cause and effect. [Reed and Kunkel (1960) came to a similar conclusion.] A planned next step is to utilize version 3.6 of the Weather Research and Forecasting Model (WRF), which includes optimizations for polar research such as improvements to sea ice thickness and snow depth on sea ice (Hines et al. 2015). WRF will be used to examine the relationship between the AFZ and summer cyclone activity through sensitivity studies that manipulate boundary conditions, such as topography and snow cover.

Acknowledgments. The authors thank three anonymous reviewers for their comments. This material is based upon work supported by the National Science Foundation (NSF) Graduate Research Fellowship Program under Grant DGE 1144083 and by NSF Grant PLR 1417016.

\section{REFERENCES}

Berner, J., and Coauthors, 2005: Arctic Climate Impact Assessment. Cambridge University Press, 1042 pp.

Blender, R., K. Fraedrich, and F. Lunkeit, 1997: Identification of cyclone-track regimes in the North Atlantic. Quart. J. Roy. Meteor. Soc., 123, 727-741, doi:10.1002/qj.49712353910.

Brodzik, M. J., B. Billingsley, T. Haran, B. Raup, and M. H. Savoie, 2012: EASE-Grid 2.0: Incremental but significant improvements for Earth-gridded data sets. ISPRS Int. J. Geoinf., 1, 32-45, doi:10.3390/ijgi1010032.

Crawford, A., and M. Serreze, 2015: A new look at the summer arctic frontal zone. J. Climate, 28, 737-754, doi:10.1175/ JCLI-D-14-00447.1.

Dai, A., and J. Wang, 1999: Diurnal and semidiurnal tides in global surface pressure fields. J. Atmos. Sci., 56, 3874-3881, doi:10.1175/1520-0469(1999)056<3874:DASTIG >2.0.CO;2.

Dodds, K., 2010: A polar Mediterranean? Accessibility, resources and sovereignty in the Arctic Ocean. Global Policy, 1, 303-311, doi:10.1111/j.1758-5899.2010.00038.x.

Dzerdzeevskii, B. L., 1945: Tsirkuliatsionnye skhemy v troposfere Tsentral' noi Arktiki. Izdatel'stvo Akademii Nauk, 28 pp.

Eady, E. T., 1949: Long waves and cyclone waves. Tellus, 1A, 33-52, doi:10.1111/j.2153-3490.1949.tb01265.x.

Farrell, B., 1985: Transient growth of damped baroclinic waves. J. Atmos. Sci., 42, 2718-2727, doi:10.1175/1520-0469(1985)042<2718: TGODBW $>2.0 . \mathrm{CO} ; 2$.

Gulev, S. K., O. Zolina, and S. Grigoriev, 2001: Extratropical cyclone variability in the Northern Hemisphere winter from the NCEP/NCAR reanalysis data. Climate Dyn., 17, 795-809, doi:10.1007/s003820000145.

Hanley, J., and R. Caballero, 2012: Objective identification and tracking of multicentre cyclones in the ERA-Interim reanalysis dataset. Quart. J. Roy. Meteor. Soc., 138, 612-625, doi:10.1002/qj.948.

Hines, K. M., D. H. Bromwich, L. Bai, C. M. Bitz, J. G. Powers, and K. W. Manning, 2015: Sea ice enhancements to Polar WRF. Mon. Wea. Rev., 143, 2363-2385, doi:10.1175/ MWR-D-14-00344.1.

Hodges, K. I., B. J. Hoskins, J. Boyle, and C. Thorncroft, 2003: A comparison of recent reanalysis datasets using objective feature tracking: Storm tracks and tropical easterly waves. Mon. Wea. Rev., 131, 2012-2037, doi:10.1175/1520-0493(2003)131<2012: ACORRD $>2.0 . \mathrm{CO} ; 2$.

-, R. W. Lee, and L. Bengtsson, 2011: A comparison of extratropical cyclones in recent reanalyses ERA-Interim, NASA MERRA, NCEP CFSR, and JRA-25. J. Climate, 24, 48884906, doi:10.1175/2011JCLI4097.1.

Hoskins, B. J., and K. I. Hodges, 2002: New perspectives on the Northern Hemisphere winter storm tracks. J. Atmos. Sci., 59, 1041-1061, doi:10.1175/1520-0469(2002)059<1041: $\mathrm{NPOTNH}>2.0 . \mathrm{CO} ; 2$.

Inatsu, M., 2009: The neighbor enclosed area tracking algorithm for extratropical wintertime cyclones. Atmos. Sci. Lett., 10, 267272, doi:10.1002/asl.238

Inoue, J., and M. E. Hori, 2011: Arctic cyclogenesis at the marginal ice zone: A contributory mechanism for the temperature amplification? Geophys. Res. Lett., 38, L12502, doi:10.1029/ 2011GL047696. 
König, W., R. Sausen, and F. Sielmann, 1993: Objective identification of cyclones in GCM simulations. J. Climate, 6, 2217-2231, doi:10.1175/1520-0442(1993)006<2217:OIOCIG>2.0.CO;2.

Ledrew, E. F., 1984: The role of local heat sources in synoptic activity within the polar basin. Atmos.-Ocean, 22, 309-327, doi:10.1080/07055900.1984.9649201.

Lim, E.-P., and I. Simmonds, 2002: Explosive cyclone development in the Southern Hemisphere and a comparison with Northern Hemisphere events. Mon. Wea. Rev., 130, 2188-2209, doi:10.1175/1520-0493(2002)130<2188:ECDITS>2.0.CO;2.

McCabe, G. J., M. P. Clark, and M. C. Serreze, 2001: Trends in Northern Hemisphere surface cyclone frequency and intensity. J. Climate, 14, 2763-2768, doi:10.1175/1520-0442(2001)014<2763: TINHSC $>2.0 . \mathrm{CO} ; 2$.

Mesquita, M. D. S., N. G. Kvamstø, A. Sorteberg, and D. E. Atkinson, 2008: Climatological properties of summertime extra-tropical storm tracks in the Northern Hemisphere. Tellus, 60A, 557-569, doi:10.1111/j.1600-0870.2008.00305.x.

- D. E. Atkinson, I. Simmonds, K. Keay, and J. Gottschalck, 2009: New perspectives on the synoptic development of the severe October 1992 Nome storm. Geophys. Res. Lett., 36, L13808, doi:10.1029/2009GL038824.

Murray, R. J., and I. Simmonds, 1991: A numerical scheme for tracking cyclone centres from digital data. Aust. Meteor. Mag., 39, 155-166.

Neu, U., and Coauthors, 2013: IMILAST: A community effort to intercompare extratropical cyclone detection and tracking algorithms. Bull. Amer. Meteor. Soc., 94, 529-547, doi:10.1175/ BAMS-D-11-00154.1.

Ogi, M., K. Yamazaki, and Y. Tachibana, 2004: The summertime annular mode in the Northern Hemisphere and its linkage to the winter mode. J. Geophys. Res., 109, D20114, doi:10.1029/ 2004JD004514.

Pezza, A. B., J. A. P. Veiga, I. Simmonds, K. Keay, and M. S. Mesquita, 2010: Environmental energetics of an exceptional high-latitude storm. Atmos. Sci. Lett., 11, 39-45, doi:10.1002/ asl.253.

Pierrehumbert, R. T., and K. L. Swanson, 1995: Baroclinic instability. Annu. Rev. Fluid Mech., 27, 419-467, doi:10.1146/ annurev.fl.27.010195.002223.

Pinto, J. G., T. Spangehl, U. Ulbrich, and P. Speth, 2005: Sensitivities of a cyclone detection and tracking algorithm: Individual tracks and climatology. Meteor. Z., 14, 823-838, doi:10.1127/0941-2948/2005/0068.

Raible, C. C., P. M. Della-Marta, C. Schwierz, H. Wernli, and R. Blender, 2008: Northern Hemisphere extratropical cyclones: A comparison of detection and tracking methods and different reanalyses. Mon. Wea. Rev., 136, 880-897, doi:10.1175/ 2007MWR2143.1.

Reed, R. J., and B. A. Kunkel, 1960: The arctic circulation in summer. J. Meteor., 17, 489-506, doi:10.1175/1520-0469(1960)017<0489: TACIS $>2.0 . \mathrm{CO} ; 2$.

Rienecker, M. M., and Coauthors, 2011: MERRA: NASA's Modern-Era Retrospective Analysis for Research and Applications. J. Climate, 24, 3624-3648, doi:10.1175/ JCLI-D-11-00015.1.

Roebber, P. J., 1989: On the statistical analysis of cyclone deepening rates. Mon. Wea. Rev., 117, 2293-2298, doi:10.1175/ 1520-0493(1989)117<2293:OTSAOC >2.0.CO;2.

Rudeva, I., S. K. Gulev, I. Simmonds, and N. Tilinina, 2014: The sensitivity of characteristics of cyclone activity to identification procedures in tracking algorithms. Tellus, 66A, 24961, doi:10.3402/tellusa.v66.24961.
Saha, S., and Coauthors, 2010: The NCEP Climate Forecast System Reanalysis. Bull. Amer. Meteor. Soc., 91, 1015-1057, doi:10.1175/2010BAMS3001.1.

Serreze, M. C., 1995: Climatological aspects of cyclone development and decay in the Arctic. Atmos.-Ocean, 33, 1-23, doi:10.1080/07055900.1995.9649522.

— the central Arctic Ocean. J. Climate, 21, 1048-1065, doi:10.1175/2007JCLI1810.1.

_ J. D. Kahl, and R. C. Schnell, 1992: Low-level temperature inversions of the Eurasian Arctic and comparisons with Soviet drifting station data. J. Climate, 5, 615-629, doi:10.1175/ 1520-0442(1992)005<0615:LLTIOT>2.0.CO;2.

_ J. E. Box, R. G. Barry, and J. E. Walsh, 1993: Characteristics of arctic synoptic activity, 1952-1989. Meteor. Atmos. Phys., 51, 147-164, doi:10.1007/BF01030491.

_, F. Carse, R. G. Barry, and J. C. Rogers, 1997: Icelandic low cyclone activity: Climatological features, linkages with the NAO, and relationships with recent changes in the Northern Hemisphere circulation. J. Climate, 10, 453-464, doi:10.1175/ 1520-0442(1997)010<0453:ILCACF > 2.0.CO;2.

— A. H. Lynch, and M. P. Clark, 2001: The arctic frontal zone as seen in the NCEP-NCAR reanalysis. J. Climate, 14, 1550-1567, doi:10.1175/1520-0442(2001)014<1550:TAFZAS>2.0.CO;2.

_ A. P. Barrett, A. G. Slater, M. Steele, J. Zhang, and K. E. Trenberth, 2007: The large-scale energy budget of the Arctic. J. Geophys. Res., 112, D11122, doi:10.1029/2006JD008230.

,$- \ldots$, and J. J. Cassano, 2011: Circulation and surface controls on the lower tropospheric air temperature field of the Arctic. J. Geophys. Res., 116, D07104, doi:10.1029/2010JD015127.

Simmonds, I., and K. Keay, 2009: Extraordinary September arctic sea ice reductions and their relationships with storm behavior over 1979-2008. Geophys. Res. Lett., 36, L19715, doi:10.1029/ 2009GL039810.

_ and E.-P. Lim, 2009: Biases in the calculation of Southern Hemisphere mean baroclinic eddy growth rate. Geophys. Res. Lett., 36, L01707, doi:10.1029/2008GL036320.

- and I. Rudeva, 2012: The great arctic cyclone of August 2012. Geophys. Res. Lett., 39, L23709, doi:10.1029/2012GL054259.

—, and - 2014: A comparison of tracking methods for extreme cyclones in the Arctic basin. Tellus, 66A, 25252, doi:10.3402/tellusa.v66.25252.

— C. Burke, and K. Keay, 2008: Arctic climate change as manifest in cyclone behavior. J. Climate, 21, 5777-5796, doi:10.1175/2008JCLI2366.1.

Sinclair, M. R., 1994: An objective cyclone climatology for the Southern Hemisphere. Mon. Wea. Rev., 122, 2239-2256, doi:10.1175/1520-0493(1994)122<2239:AOCCFT>2.0.CO;2.

_ 1997: Objective identification of cyclones and their circulation intensity, and climatology. Wea. Forecasting, 12, 595-612, doi:10.1175/1520-0434(1997)012<0595:OIOCAT >2.0.CO;2.

Sorteberg, A., and B. Kvingedal, 2006: Atmospheric forcing on the Barents Sea winter ice extent. J. Climate, 19, 4772-4784, doi:10.1175/JCLI3885.1.

— and its impact on moisture transport into the Arctic. Tellus, 60A, 570-586, doi:10.1111/j.1600-0870.2008.00314.x.

Tanaka, H. L., A. Yamagami, and S. Takahashi, 2012: The structure and behavior of the arctic cyclone in summer analyzed by the JRA-25/JCDAS data. Polar Sci., 6, 55-69, doi:10.1016/ j.polar.2012.03.001.

Tilinina, N., S. K. Gulev, and I. Rudeva, 2013: Comparing cyclone life cycle characteristics and their interannual variability in 
different reanalyses. J. Climate, 26, 6419-6438, doi:10.1175/ JCLI-D-12-00777.1.

Trigo, I. F., 2006: Climatology and interannual variability of stormtracks in the Euro-Atlantic sector: A comparison between ERA-40 and NCEP/NCAR reanalyses. Climate Dyn., 26, 127 143, doi:10.1007/s00382-005-0065-9.

— T. D. Davies, and G. R. Bigg, 1999: Objective climatology of cyclones in the Mediterranean region. J. Climate, 12, 1685-1696, doi:10.1175/1520-0442(1999)012<1685:OCOCIT>2.0.CO;2.

Vallis, G. K., 2006: Atmospheric and Oceanic Fluid Dynamics. Cambridge University Press, 745 pp.

Vavrus, S. J., 2013: Extreme arctic cyclones in CMIP5 historical simulations. Geophys. Res. Lett., 40, 6208-6212, doi:10.1002/ 2013 GL058161.

Walter, K., and H.-F. Graf, 2005: The North Atlantic variability structure, storm tracks, and precipitation depending on the polar vortex strength. Atmos. Chem. Phys., 5, 239-248, doi:10.5194/acp-5-239-2005.
Welsh, J. P., R. D. Ketchum Jr., A. W. Lohanick, D. T. Eppler, L. D. Farmer, R. E. Burge, and C. A. Radl, 1986: A Compendium of Arctic Environmental Information. National Space Technology Laboratory, $142 \mathrm{pp}$.

Wernli, H., and C. Schwierz, 2006: Surface cyclones in the ERA-40 dataset (1958-2001). Part I: Novel identification method and global climatology. J. Atmos. Sci., 63, 2486-2507, doi:10.1175/ JAS3766.1.

Whittaker, L. M., and L. H. Horn, 1984: Northern Hemisphere extratropical cyclone activity for four mid-season months. J. Climatol., 4, 297-310, doi:10.1002/joc.3370040307.

Zhang, X., J. E. Walsh, J. Zhang, U. S. Bhatt, and M. Ikeda, 2004: Climatology and interannual variability of arctic cyclone activity: 1948-2002. J. Climate, 17, 2300-2317, doi:10.1175/ 1520-0442(2004)017<2300:CAIVOA >2.0.CO;2.

Zolina, O., and S. K. Gulev, 2002: Improving the accuracy of mapping cyclone numbers and frequencies. Mon. Wea. Rev., 130, 748-759, doi:10.1175/1520-0493(2002)130<0748:ITAOMC > 2.0.CO;2. 